\title{
The Existence of Street Vendors (PKL) as Supporting Activities in Jalan Taman Siswa, Semarang
}

\author{
Isna Pratiwi ${ }^{1, a)}$, Suzanna Ratih Sari ${ }^{1, b)}$, Agung Budi Sardjono ${ }^{1, c)}$ \\ ${ }^{1}$ Architecture, Faculty of Engineering, Diponegoro University. \\ a) Corresponding author: nana.isnapratiwi@gmail.com \\ b) ratihsaris@yahoo.com \\ c) abskempung@yahoo.com
}

\begin{abstract}
Sekaran area has rapidly developed nowadays, especially the development of street vendors' existence as the facility of fulfilling students' needs from the very first establishment of Unnes. There is not only street vendors' phenomenon but also there exist change of land function, the development of building and traffic density. Several additional activities to the developed area would relatively increase such impacts towards street vendor development in Sekaran, especially in Jalan Taman Siswa. This phenomenon is interesting to be studied because a part of Jalan Taman Siswa becomes one of the important corridors in Semarang State University area. This corridor, unfortunately, has been changed into the center of street vendors. The data collecting employed by the writer was observation, interview, and documentation. This study employs qualitative approach. Whereas the method used is descriptive design. By implementing this method, the writer will elaborate the problems appeared briefly and comprehensively. Theoretical data are collected by reviewing the related literature, which means that the writer gathers the data by reading much relevant literature. This data is managed by conducting analysis and applying the data to the study. The existence of Unnes as one of the big campuses in Semarang triggers the occurrence of several students' activities such as to fulfill students' daily necessity. Along Kinanti boarding house to Ulul Albab Mosque, there exist several supporting facilities for Unnes students and people around the campus. This is interesting since the occurrence of supporting activity such as PKL in that area has the strong relationship with the use of public spaces. Thus, it could be formulated that the presence of PKL as activity support in Taman Siswa corridor increases along with the development of Semarang State University Campus.
\end{abstract}

Keywords : street vendors (PKL), activity support, street corridor, Jalan Taman siswa, Semarang state university

\section{INTRODUCTION}

The development of city takes place along with the development of citizen number which is supported by public space demand [1]. Whereas, Febriyanti [2] states that the demand for land substitution would be greater according to the number of students on campus so that it would increase citizen growth in the dense settlement. The great numbers of UNNES students in Sekaran area would bring significant impact towards citizen of surrounding area. This condition is supported by [2] who said that campus or university is regarded as the small community that able to trigger the city growth.

Sekaran area has now become the developed area, especially regarding street vendors (PKL) as facilitating students' daily necessity since the first establishment of Unnes. In addition, there also exist several changes both change in land function, building density and traffic density. By moving to Sekaran in 1997, Unnes supported the increase of citizen (both permanent and temporary) in Sekaran area. The formation of the quiet place to the dense area would relatively increase the number of activities, one of which is the development of PKL in Sekaran, especially in Jalan Taman Siswa.

Regarding this interesting phenomena, this study is worthed to be conducted because in Taman Siswa corridor that in former become the important access for students on campus, now turns into vendors (PKL) center. This study focused in along Kinanthi Boarding house to Ulul Albab Mosque, because this area is near to public facilities such as market, football field, and mosque. 
According to [3], street vendors or also known as PKL is defined as existing informal sector provided in every city that sells both goods and services and which is primarily not registered by the local government. The street vendor is regarded as the flexible sector which means that every people from various background (especially from low/small economic background), relatively limited budget, low human resources, and unskilled ones can build their food stall or be street vendors. Thus, those factors become the consideration of why that can't be regulated by the government in the economic sector.

According to [4], the primary function of activity support is to connect one or more activity center to be lively, continuous and crowded area. While according to [5] and [6] said that the number of economic activity could be indicated easily based on the local resource, labor-intensive, in a relatively small scale, private, autodidact, adaptive technology, against the regulation and highly competitive.

In Indonesia, there are at least 11 basic characteristics in the informal sector [7], such as business unit which has no business permission, self-owned capital, with applying simple technology, relatively small capital, flexible work time, unorganized workplace, one-man enterprise, family workers as well. Government policy, at this point, does not touch the PKL territory, so that this kind of business would be easily shifted into another sector which does not require any education qualification, besides the consumers are mostly coming from lowclass people.

MC. Gee and Yeung [8] argue that spread pattern of PKL is divided into two main patterns, such as Linear and Cluster pattern. Besides, the center of the growth government has to possess at least four characteristics, i.e., internal relationship between several economic activities, the existence of multiplier effect, geographical concentration and supporting the growth of region [9]. [10] assumed that density issues become main problems in the urban area.

From this assumption, it can also be said that there are no spaces left in the urban area. Along with this, [11] supports the existence of campus could be the main attraction for the sake of the development of services and spatial urbanization in particular area. However, every campus owns its ability to trigger the vicinity. However, [12] stated that the existence of campus could trigger the growth of its surrounding through its public services.

\section{METHOD}

This study employs qualitative approach. Whereas, the method used is descriptive design. By implementing this method, the writer will elaborate the problems appeared briefly and comprehensively. Theoretical data are collected by reviewing the related literature, which means that the writer gathers the data by reading much relevant literature. This data is managed by conducting analysis and applying the data to the study.

\section{RESULT AND DISCUSSION}

Sekaran one of the region in Southern Semarang that has $490.718 \mathrm{Ha}$ width. According to the data, the number of the permanent citizen in 2017 was approximately +8.428 people, while students and vendors as the contemporary citizens were as much 30.000 people, whereas the density of this area was 78 people/hectare. Sekaran area is located in southern Semarang where the city function of this section is for the education sector.

The presence of Semarang State University or Unnes in Jalan Taman Siswa corridor has become the trigger to the occurrence of students' activity support such as the daily necessity for students. Part of Jalan Taman Siswa there exist numerous facilities as activity supports for both students and people around the campus. This is interesting because PKL is strongly related to the public space impacts that would be discussed in this study.

Various activities in this region are mostly dominated by informal sectors (street vendors/PKL) and temporary market (spot market). For the further illustration, this following table is provided. For the further illustration, this following table is provided.

TABLE 1. Research Variables

\begin{tabular}{ccc}
\hline No. & Type of Activity & Activity Time \\
\hline 1 & Settlement & 24 Hours \\
2 & Offices & $07.00-16.00 \mathrm{WIB}$ \\
3 & Lectures & $07.00-18.00 \mathrm{WIB}$ \\
4 & Street Vendors (PKL) & $05.00-22.00 \mathrm{WIB}$ \\
\hline
\end{tabular}

Referring the analysis, it can be seen that according to its equipment, PKL can be identified to PKL with mat, PKL with food stall, PKL with vehicle and so forth. 


\section{Types of PKL in Jalan Taman Siswa}

There are at least 11 categories or types of PKL in Jalan Taman Siswa. They have several characteristics such as:

\section{PKL with stall (Selling Fruit and Vegetable)}

In Figure 1, it is seen that PKL sell raw vegetable using the stall. Vegetable stall usually opens daily from 07:00 to 12:00 a.m. Most of the PKL have to spend at least IDR. 500,000 for rent spaces, IDR 2,000 for daily fare, and IDR. 2,000 for regular cleaning service to the PKL community. This location is very strategic and easy to be accessed by students, employees of Unnes and permanent citizen to fulfill their daily necessity. The spot for selling the goods is strategic that is near to the boarding houses so it will give a good opportunity for the vendors to promote their products inside the football field.
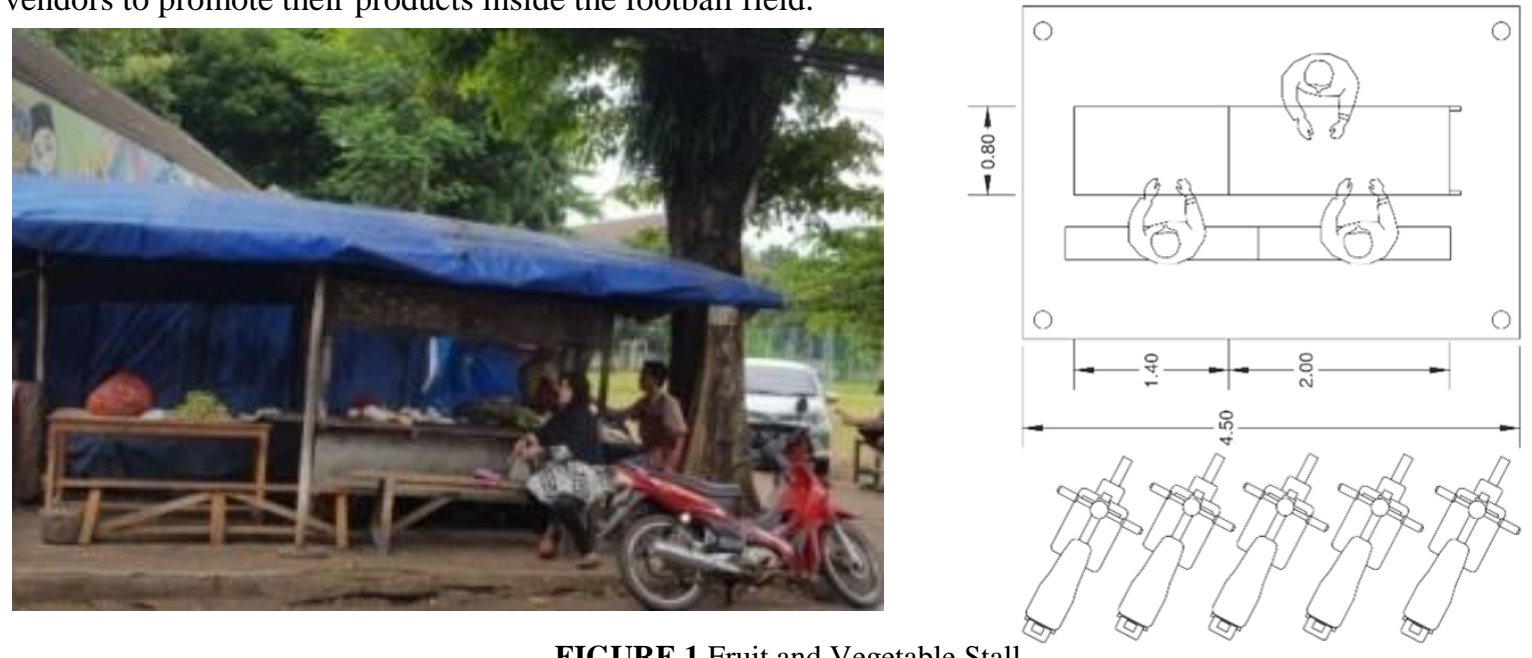

FIGURE 1 Fruit and Vegetable Stall

\section{Stall with Cooking Equipment}

In figure 2, it can be seen that this PKL starts their business from 10:00 a.m. to 09:00 p.m. This PKL need to spend IDR. 2,000 daily for retribution fare and IDR 5,000 for cleaning service. Street food vendor said that they also need to add extra IDR. 5,000 for electricity to the PKL community. He owns strategic location to sell his product since the traffic of activities in this is relatively high.
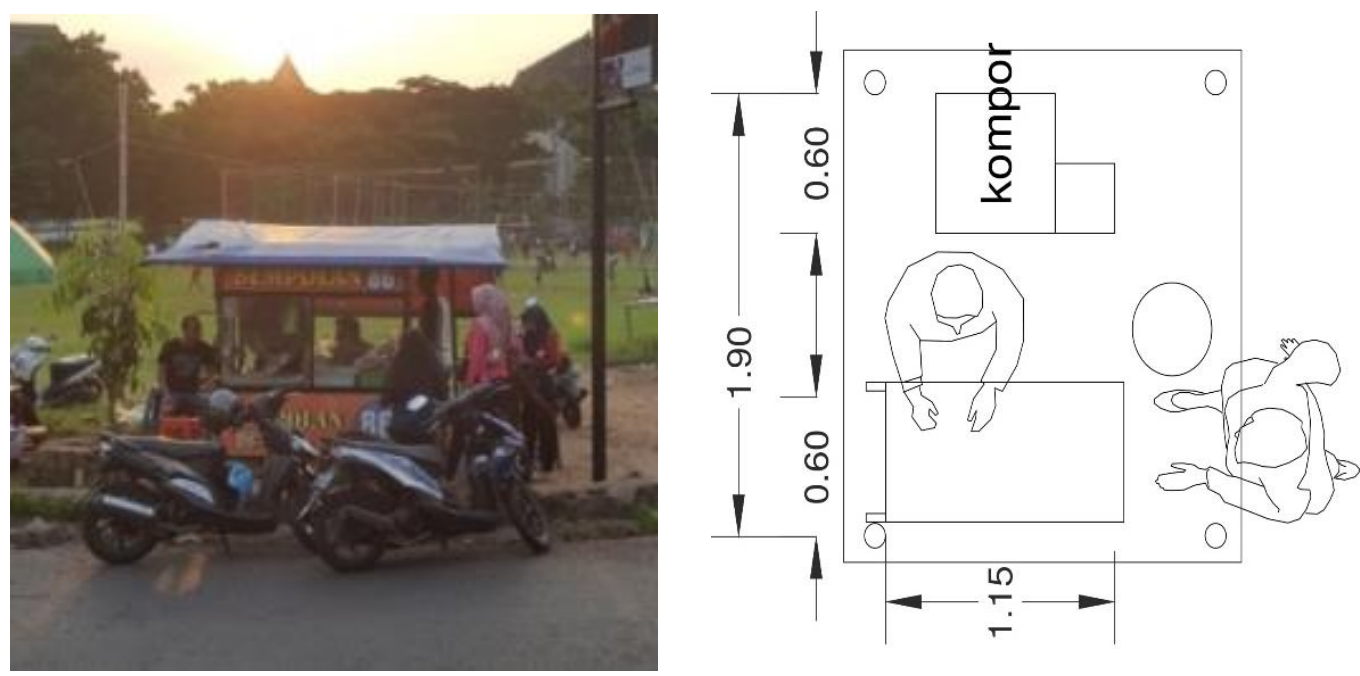

FIGURE 2 PKL who sells street food

\section{Food and Beverage Stall}

This vendor usually opens at 07:00 a.m. to 05:00 p.m. in front of Ulul Albab Mosque. Street food vendor chose this place (by not moving to another place) because many customers frequently complain about the 
difficulty of looking for their existence when they needed. Thus, this vendor decided to stay to spoil his/her customers.
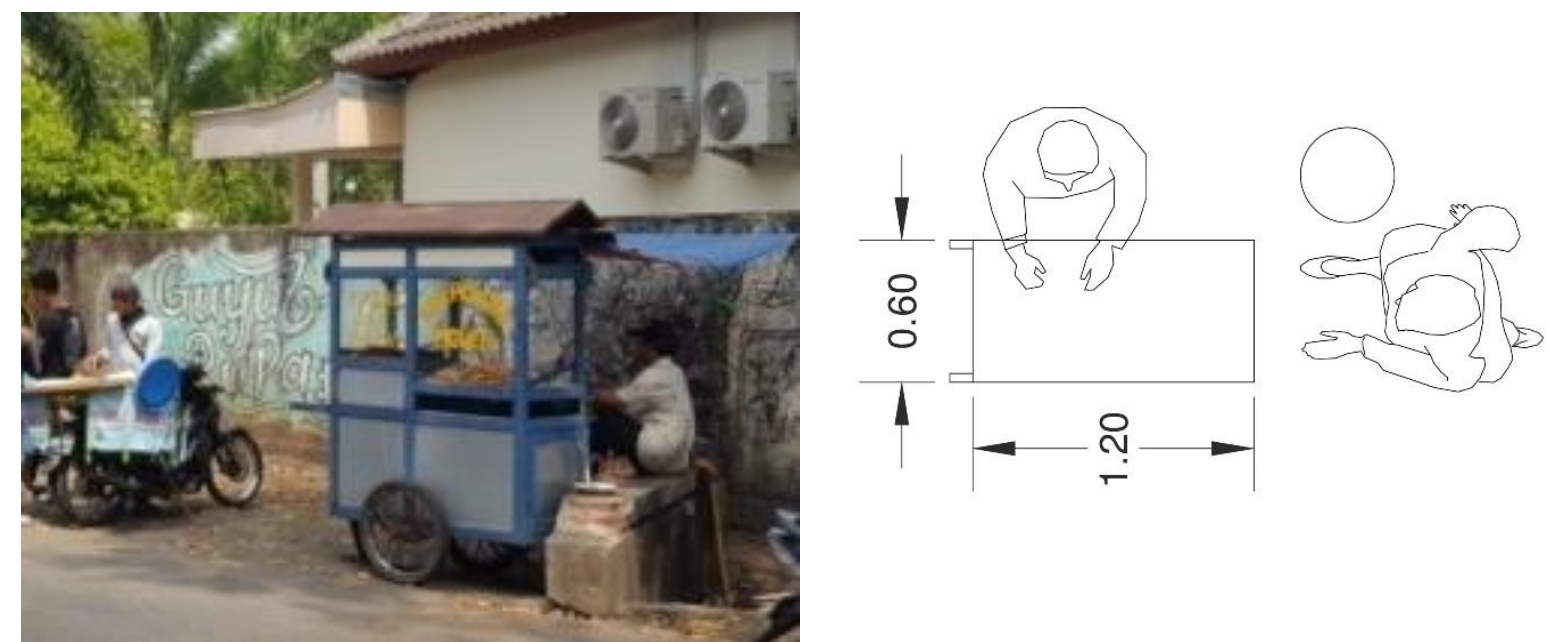

FIGURE 3 Street food vendor

\section{Food Stall with Motorcycle / mobile stall}

Figure 4 stated that this PKL utilized motorcycle to sell chicken porridge. This vendor sells his food in front of the temporary market area from 06:00-10:00 in the morning. Once the porridge is still available, then he would only go around the campus or vicinity to look for customers. The location chosen by this vendor is very strategic. It is located in front of the temporary market, the center of activity of people and students in Sekaran.
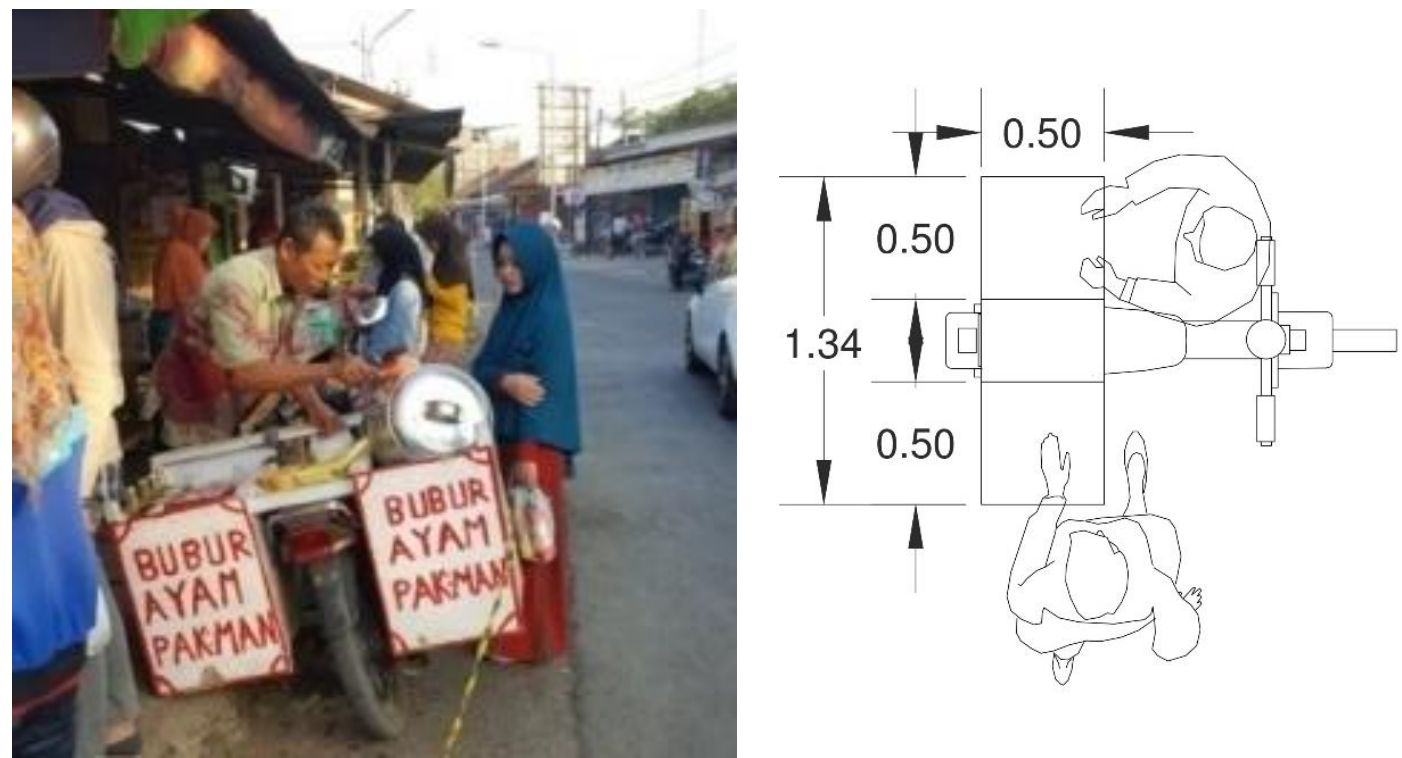

FIGURE 4 Chicken Porridge Vendor

\section{Fruit and Vegetable Vendor using Table}

This figure 5 indicates that there are several street fruit vendors in the temporary market area. Usually, it is open daily started at 06:00. a.m. to 12:00 a.m. All of the equipment needed by the vendor has been permanently integrated into this area, so it cannot be moved anywhere. They have to pay for retribution fee to the community. They need to spend at least IDR. 2,000 every day. However, unfortunately, the environment of this temporary market is not clean. This is because people (both vendors and customers) do not have enough education and awareness about clean lifestyle. 

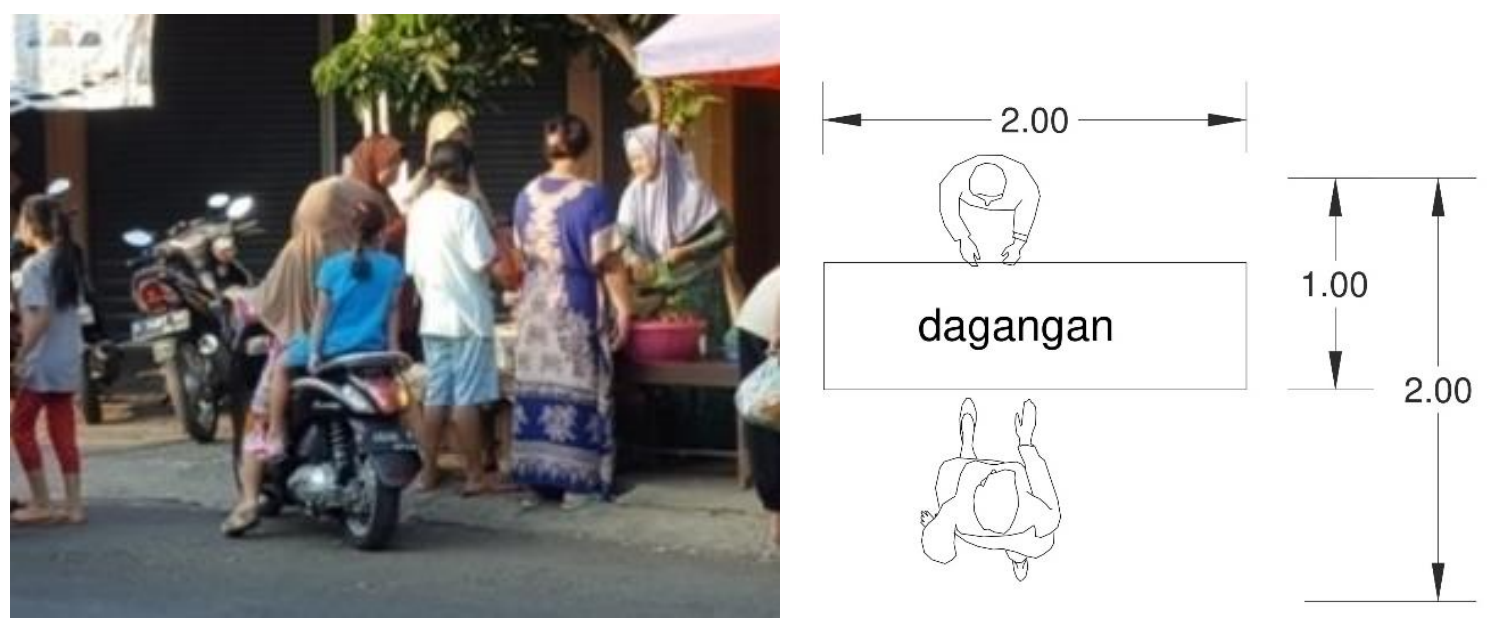

FIGURE 5 PKL with Fruit and Vegetable

\section{Food and Beverage Stall using Table}

This vendor uses a table as the equipment for selling foods. This vendor tends to sell porridge at around 06:00 - 08:00 in the morning to provide breakfast menu for students and people in the vicinity. Fortunately, those who only use the area in the temporary market area for less than 3 hours will not have the responsibility to pay the retribution fare.
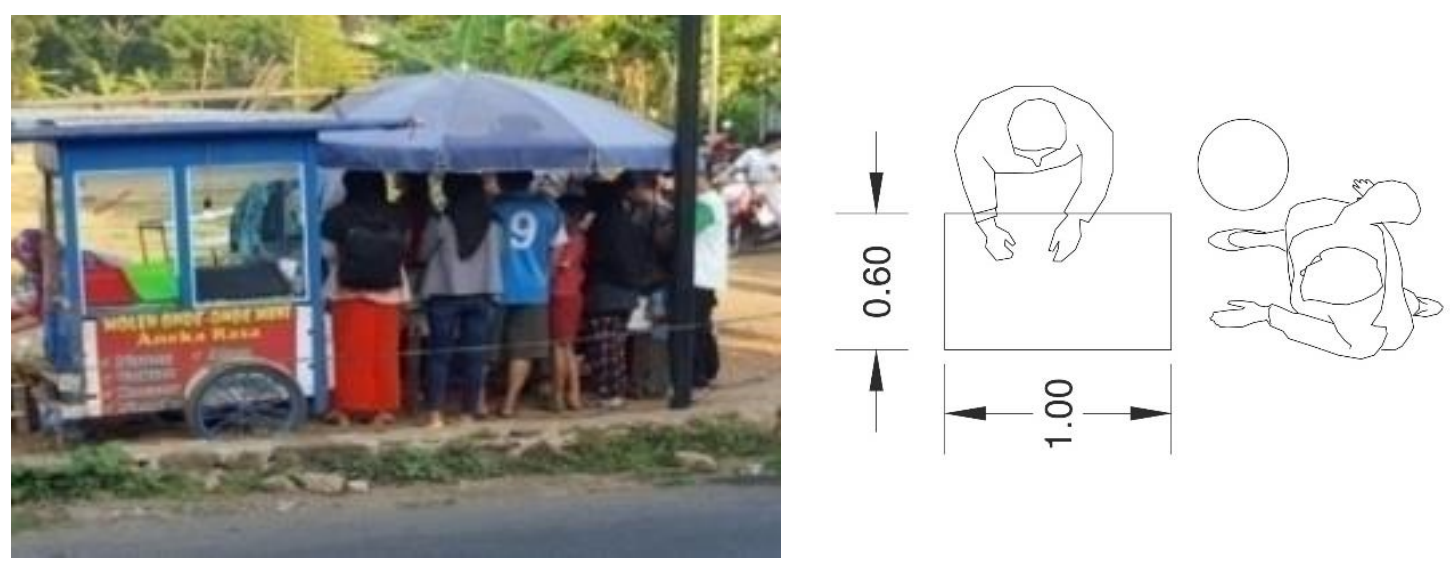

FIGURE 6 Street food vendor

\section{Vendors with Table and Cooking Equipment}

This vendor utilizes table to sell street food. These vendors operate from 06:00 to 10:00 a.m to provide breakfast for the citizen. The location chosen is very strategic, indeed because it is located in the center of Jalan Taman Siswa. By selling in the crowded area will increase their income. However, many people less aware of the rubbish and environment health, the condition of this place is getting worse. The arrangement of the vendors is not well-organized, so it creates slum and the dirty area along Jalan Taman Siswa corridor. 

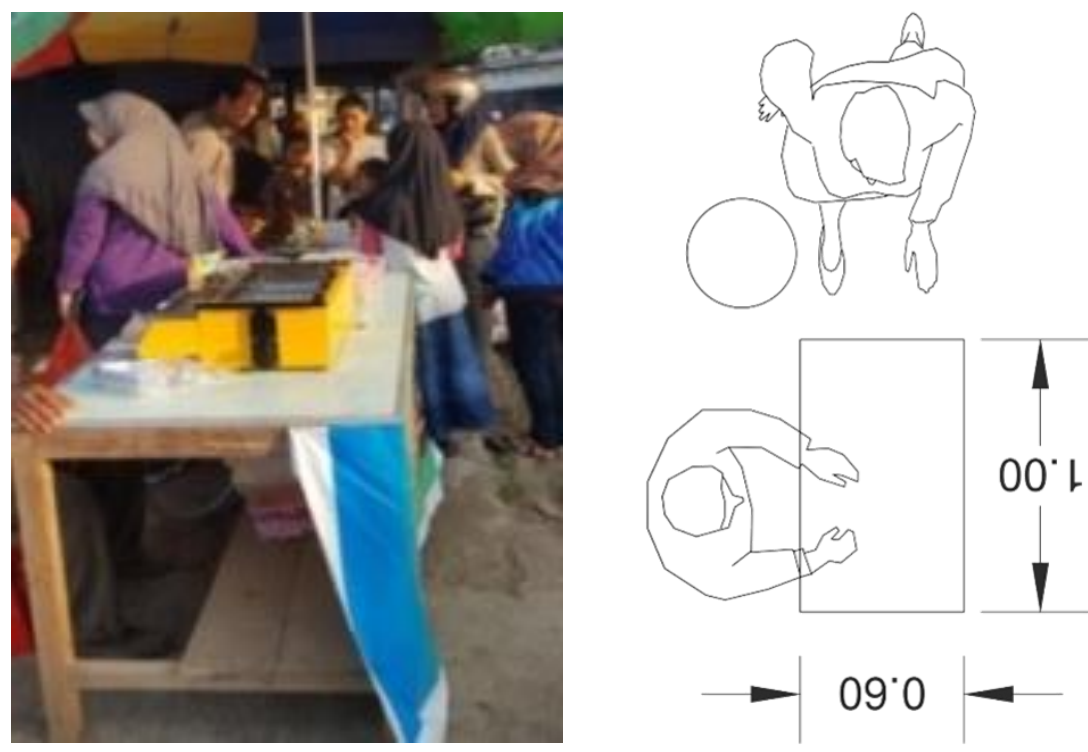

FIGURE 7 Street food vendor

\section{Vendors with Mat}

Vendors who sell clothes using mat is usually located in front of Krempyeng market, and it opens daily from 06:00 - 09:00 a.m. It can be seen that all clothes are put on the mat in the pedestrian path without considering space for people to walk. They do not need to pay for retribution because they have the shorter duration (at least 3 hours). In addition, their existence cannot be predicted because they will move anywhere to find customers. The benefit of using the mat for selling something is less space and can optimize the goods to sell so it will increase their income. They also choose this location because it is relatively strategic.
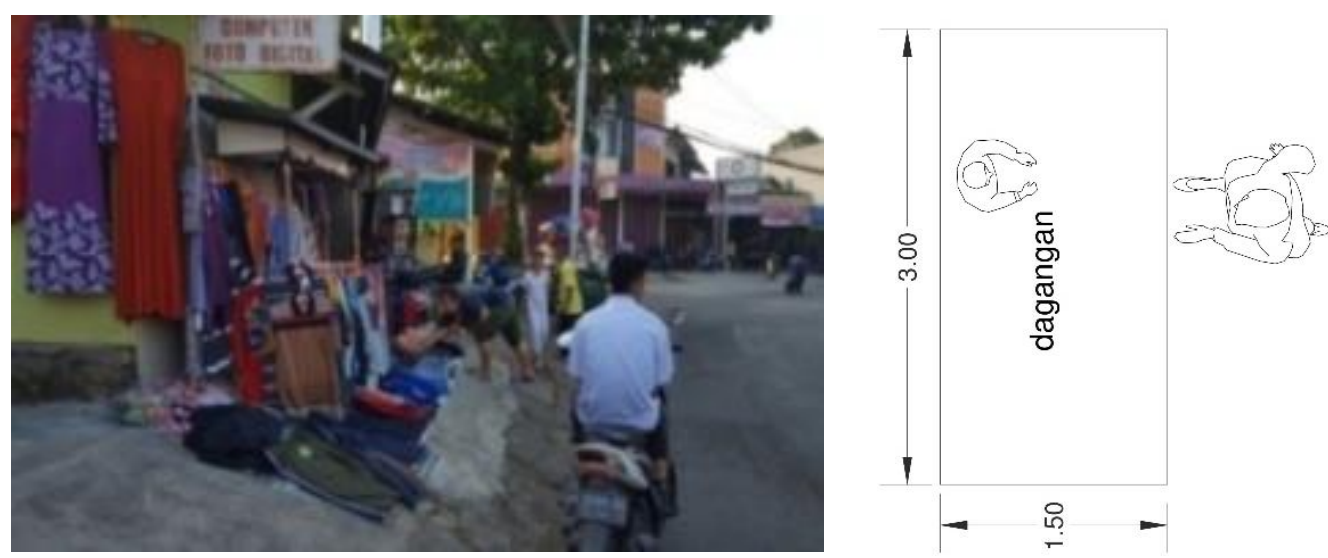

FIGURE 8 Clothes vendors

\section{Vendors with Tent}

Food stalls with this type (booth and tent) are open daily from 06:00 - 10:00 p.m in the evening. Selling goods using tent is safer and more comfortable for both vendor and customers. Because it will keep the people from hot and rain. Besides, foods provided will look even cleaner. This location is strategic, and it is believed to attract more customers to increase more income. 

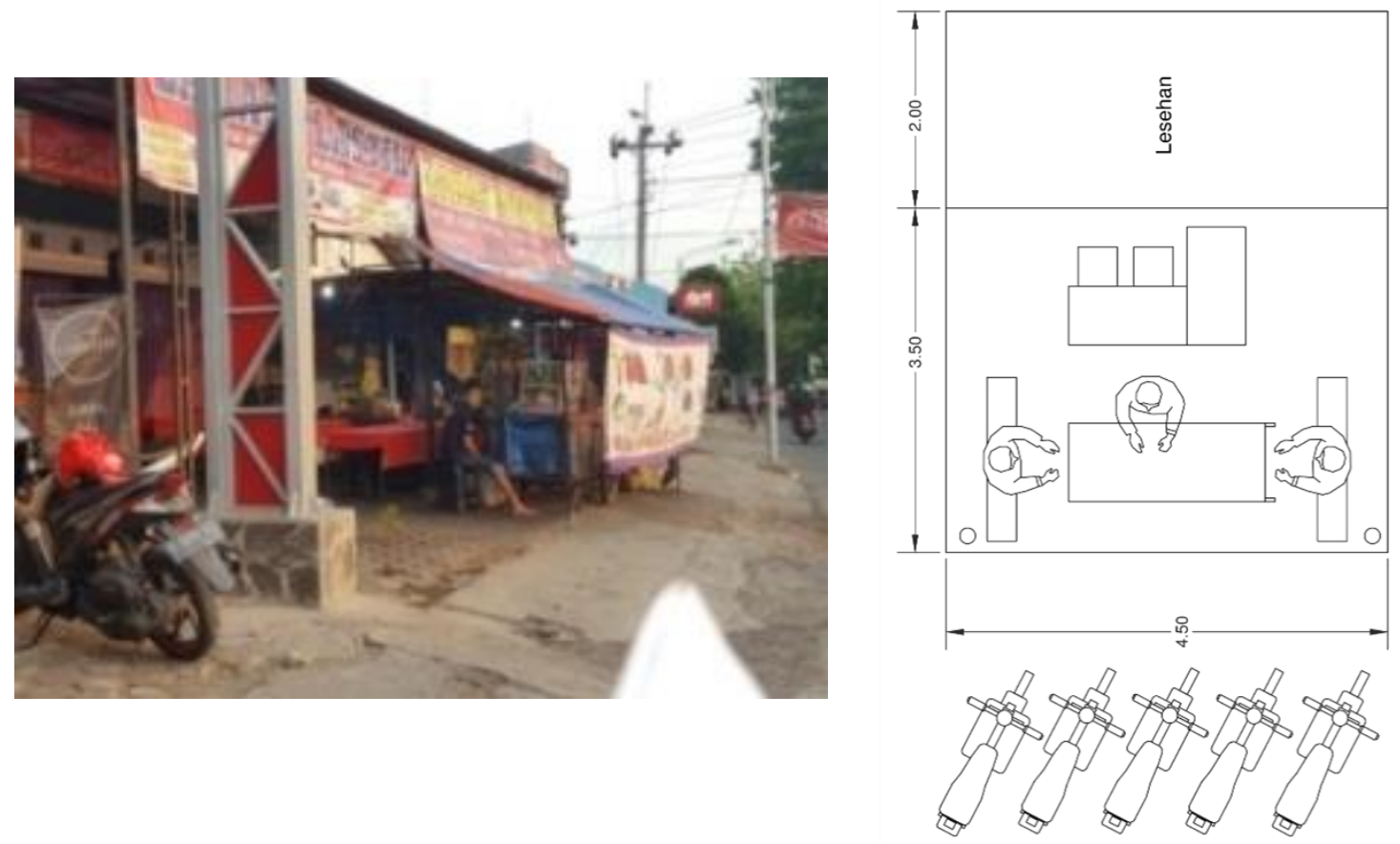

FIGURE 9 Nasi Penyet vendor with Tent

\section{Street Vendors Pattern}

The street vendor (PKL) in Jalan Taman Siswa has Linear pattern [13]\&[14] by making use of parking lot inside the field. However, the existence of parking lot has become less effective because many visitors park their vehicle in the road body since they assume that the parking area is relatively far from the street vendors spot.

Figure 11-12 illustrates the spread pattern of PKL in Jalan Taman Siswa in the morning and in the evening.

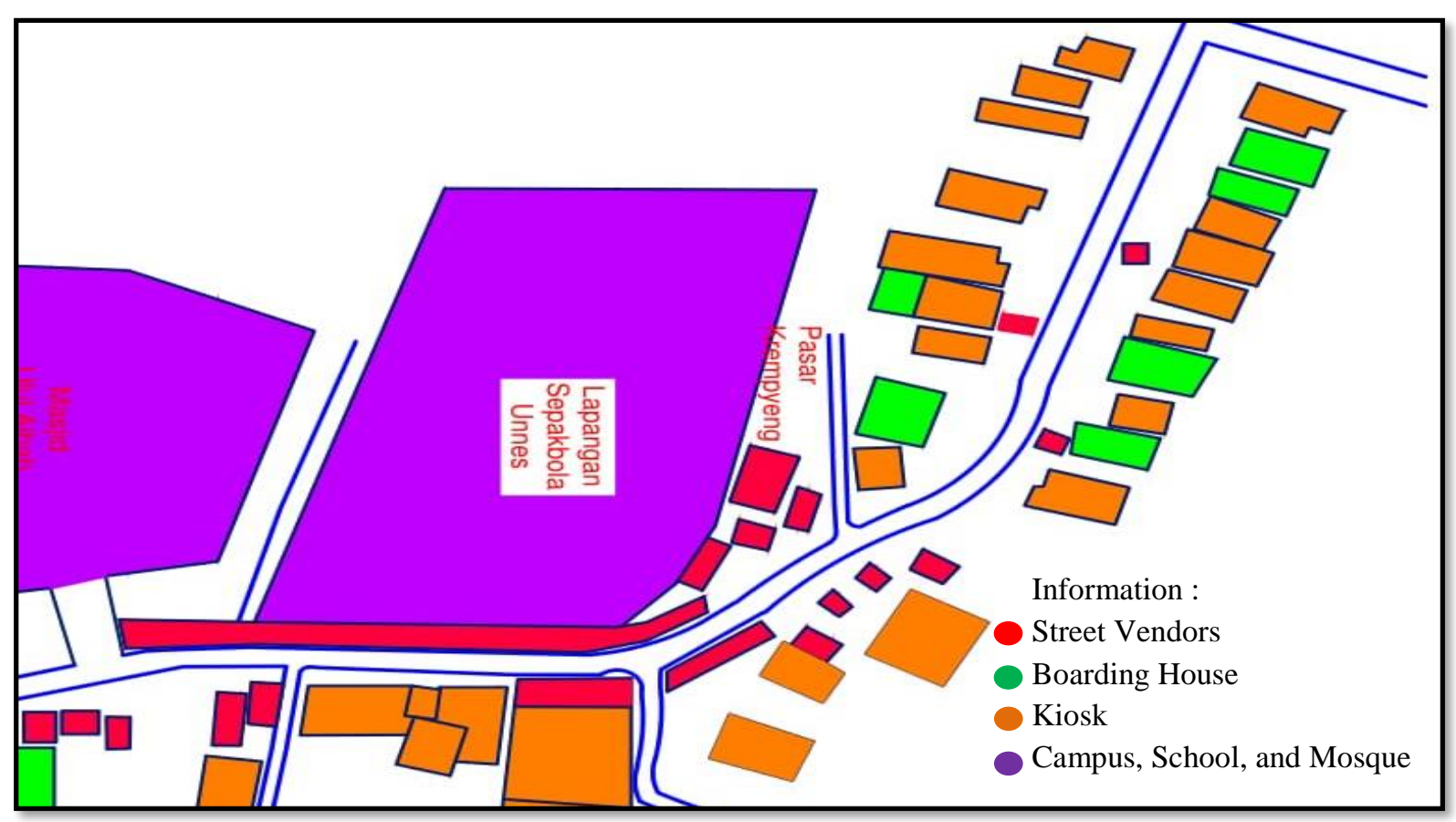

FIGURE 10 Street Vendors Pattern 


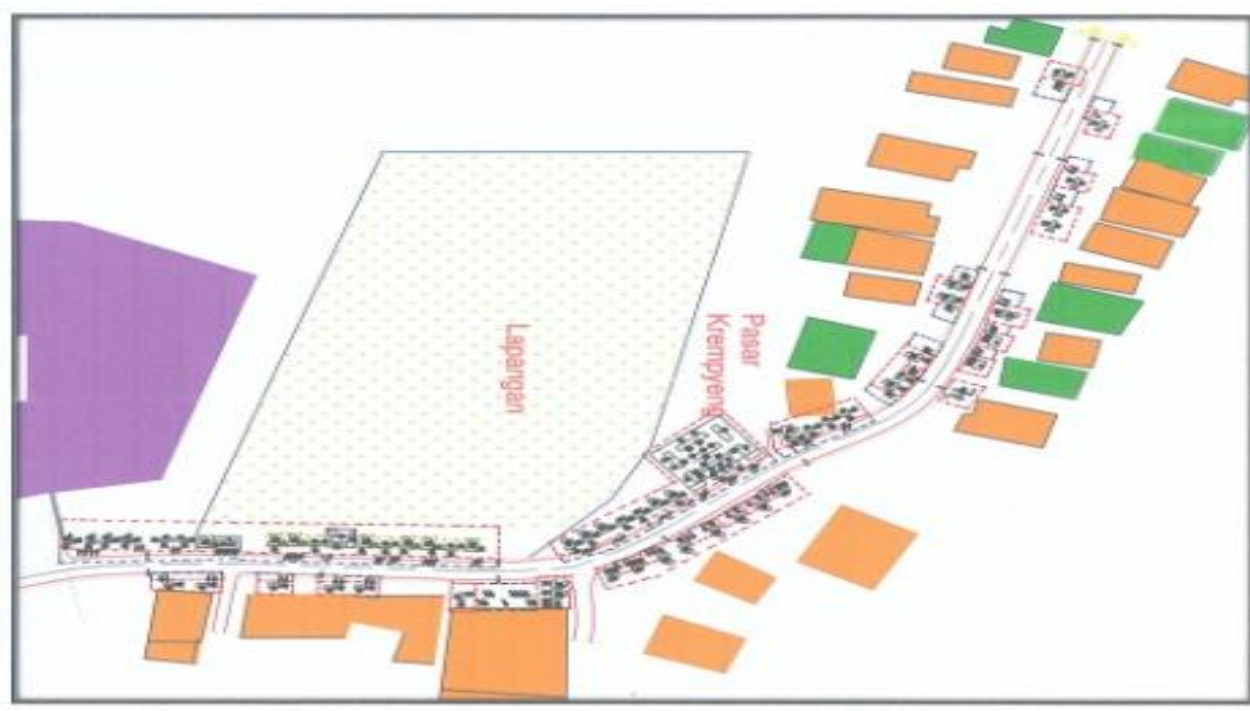

Information :

Street Vendors

Boarding House

Kiosk

Campus, School, and

Mosque

FIGURE 11 Spread pattern of PKL in the morning

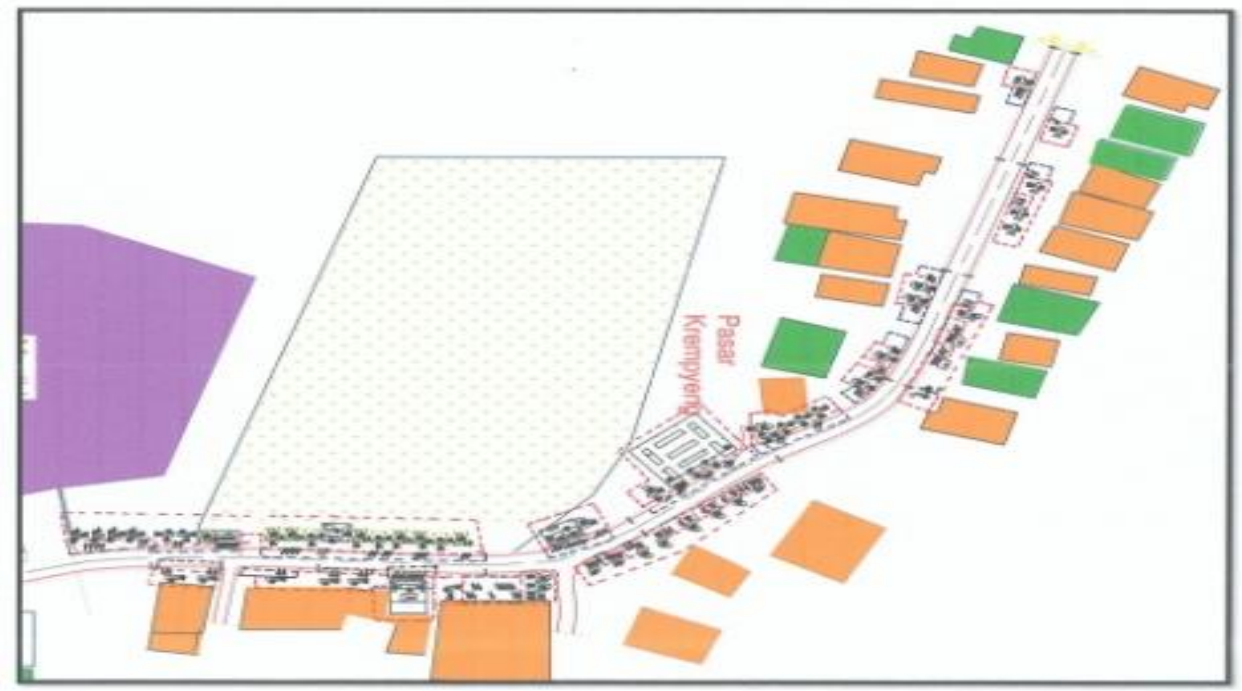

Information:

Street Vendors

Boarding House

Kiosk

Campus, School, and

Mosque

FIGURE 12 PKL pattern in the evening

It can be seen that most of the PKL in Taman Siswa corridor equips stall and tent to sell their products. They merely occupy public spaces to sell and promote their foods such as in football field, traditional unorganized market (Krempyeng Market), in front of Kios, and in front of the mosque of Unnes. They shift their stall or tent in the morning and evening. Most of the PKL started to open their booth at 5.00 p.m to 10.00 p.m.

According to the analysis, most of the street vendors in this area have the particular equipment such as mat, stall, table, truck, car and so forth. However, most of the street vendors would prefer tent because it provides the more permanent spot to sell their food. Street vendors using tents could be easily found in this area of study, especially those who are located in front of school and kiosk. Due to tent spend more spaces than stall or any other types, the rent for this location is relatively expensive.

Finally, it could be taken into conclusion from Figure 11 and 12 that street vendors in segment 1 has the linear pattern with parking lot inside the field, whereas the existence of parking lot is less useful because it is too far from the street vendor spot. The management only requires the owner of PKL to park their vehicle in the parking area inside area of Unnes mosque. Besides, PKL in krempyeng market is required to park their vehicle inside the field. However, as there is no strict rule about this, both PKL and visitors are free to park their vehicle anywhere without considering the regulation. In addition, traffic jam is frequently occurred as the result of this improper activity.

The formation of the linear pattern is supported by the management influence that kindly takes care about the placement of the PKL stall. The position of street vendors in one line and which are located within the field 
is very beneficial for both seller and customer. Because the space created between them can be used as "waiting space" for the customer while waiting for the food they ordered.

\section{CONCLUSION}

From the study conducted in Jaan Taman Siswa in Unnes, it can be concluded that the existence of the State University of Semarang in Sekaran would trigger the appearance of street vendors that employ Taman Siswa corridor as one of the facilities for fulfilling people's needs especially students, employees, and inhabitants.

There are several spaces used by street vendors to sell their products, such as football field, temporary market, in front of the Kiosk, in front of Ulul Albab mosque along Jalan Taman Siswa. Those vendors will share the place to sell their products, some of them open in the morning, and some other will open in the evening.

There are also varies in types with numerous numbers. Even parking area is formed to be the spot for vendors to sell their goods and services. Thus, customers make use of the street body to park their vehicle when they want to buy food so that the crowded and traffic jam is inevitable.

From this conclusion, it also can be formulated that the existence of PKL as the Activity Support in Jalan Taman Siswa Corridor improves as the primary activity on Campus of Unnes.

\section{REFERENCES}

[1] Pontoh, Nia K \& Kustiawan, Iwan. 2009. Pengantar Perencanaan Perkotaan. Bandung: Penerbit ITB.

[2] Febrianti, D., 2009. Penyelenggaraan Makanan, tingkat Konsumsi dan Analisis Preferensi Atlet di SMA Negeri Ragunan Jakarta, Skripsi Mahasiswa Departemen Gizi Masyarakat fakultas Ekologi Manusia IPB. Bogor.

[3] Evers, Hans Dieters dan Rudiger, Korf. 2002. Urbanisasi di Asia Tenggara : Makna dan Kekuasaan di Ruang - Ruang Sosial. Jakarta : Yayasan Obor Indonesia.

[4] Carolina, Anastasia. 2007. Pengaruh Keberagaman Activity Support Terhadap Terbentuknya Image Koridor (Pratesis) Studi Kasus Koridor Jalan Prof. Sudharto. UNDIP. Semarang

[5] Setyowati, Sri Utami. 2004. Penataan Pedagang Kaki Lima Dengan Memanfaatkan Ruang Luar Di Pusat Kota (Kasus : Pedagang Kaki Lima Di Taman Surya Surabaya). Jurnal Neutron, Vol.4, No. 2, Agustus 2004

[6] Safaria, dkk. 2003. Hubungan Perburuhan Di Sektor informal. Bandung: Yayasan AKATIGA.

[7] Hidayat. 2012. Dampak Sosial Ekonomi Relokasi Pedagang Kaki Lima Di Kawasan Simpang Lima Dan Jalan Pahlawan Kota Semarang. Semarang : Economics Development Analysis Journal 1. Vol. 2.

[8] Haryanti. 2008. Karakter Berlokasi Pkl Sebagai Faktor Penting Dalam Strategi Penataan Ruang Kota. Surakarta : Seminar Nasional Pengendalian Pemanfaatan Ruang Kerjasama Kementrian PU dan PWK UNS.

[9] Taringan, R. 2005. Rencana Pembangunan Wilayah. Jakarta : Penerbit PT Bumi Aksara.

[10] Nugroho, Agung Cahyo. 2009. Kampung Kota Sebagai Sebuah Titik Tolak dalam Membentuk Urbanitas dan Ruang Kota Berkelanjutan. Jurnal Rekayasa Vol. 13 No. 3, Desember 2009.

[11] Rachmawati, Rini. 1999. Peranan Kampus Sebagai Pemicu Kegiatan Pelayanan dan Urbanisasi Spasial Serta Faktor-faktor yang Mempengaruhi. Studi Kasus di Pinggiran Kota Yogyakarta. Yogyakarta : Tesis Magister Perencanaan Kota dan Daerah Universitas Gadjah Mada.

[12] Yakobus, Suban. 2000. Dampak Keberadaan Kampus Terhadap Perkembangan Usaha Pelayanan dan Jasa : Studi Kasus di Kawasan BWK III Kota Kupang. Jogyakarta : Tesis Universitas Gajah Mada.

[13] McGee, T.G. \& Yeung, Y.M. 1977. Hawkers in Southeast Asian Cities: planning for the Bazaar Economy. Ottawa: International Development Research Centre

[14] Rahayu, Murtanti Jani, dkk. 2016. Faktor-Faktor yang Mempengaruhi Keberhasilan Penataan PKL sebagai Strategi Penataan Ruang Kota Surakarta. Region Jurnal Pembangunan Wilayah dan Perencanaan Partisipatif Vol. 7 No. 2 